\title{
The Introduction of Classic Batik Motif to the Community Through Game
}

\author{
Elisa Purnamasari ${ }^{1}$ \\ Erdhi Widyarto Nugroho, ST.,MT ${ }^{2}$ \\ Albertus Dwiyoga Widian, S. Kom., M. Kom ${ }^{3}$ \\ yosephine.elisaa@gmail.com ${ }^{1}$ \\ erdhi@unika.ac.id² \\ yoga@unika.ac.id ${ }^{3}$ \\ Information System Program, Faculty of Computer Science \\ Soegijapranata Catholic University \\ Jl. Pawiyatan Luhur IV/1 Bendan Dhuwur Semarang 50234
}

\begin{abstract}
Batik is a wealth of Indonesian nation's cultural heritage and has been registered in the Representative of the Masterpiece of the Oral and Intangible Heritage of Humanity by UNESCO in 2009 [1]. The appearance of a variety of batik would be a pleasure for batik lovers often used as clothing, furniture, or other equipment in everyday life.

However, the lack of knowledge of meaning and philosophy in batik itself is often being used indiscriminately without knowing the intentions contained in the batik itself and being a mistake in its use [2], especially in classic batik that is still abundant with tradition and custom philosophy in it [3].
\end{abstract}

This report contains the introduction of classic batik motifs and philosophies that are packaged in interactive educational games. This game is made by entering the element of trivia quiz as an evaluation material and equipped with batik information that can be read repeatedly outside the gameplay so as to enrich and give better understanding of the information in the game.

From the results of a survey of 50 respondents from the age range between 13 30 years old located in Central Java and outside Central Java, showed that this educational game about batik could make respondents become richer with knowledge about the meaning and philosophy of classical batik. In addition, respondents also desired to preserve batik as a nation's wealth.

Keywords: Classic Batik, Educational Game, Android Game

\section{INTRODUCTION}

Batik is a work of visual art made of textile material. Indonesians wear batik as a regional identity, where every motive that exists contains a value of life in social life [4]. Batik as an Indonesian cultural heritage successfully championed in front of UNESCO and included in Masterpiece of the Oral and Intangible Heritage of Humanity [1].

After the recognition, the existence of batik becomes one of the valuable assets of the country. In just four years, Indonesia was able to increase export revenue of batik which was originally USD32 Million in 2008 to USD278 Million in 2012.In addition, based on the quarter I / 2013, the number of batik export in Indonesia increased to $18.49 \%$ compared to the year 2011 with the same period [5].The development of batik seems to be balanced with the human creativity that is able to make batik with various materials so that batik is not only as a work of art but also used in various needs, 
and not only in terms of fashion but also as a complement to the interior [6].

However, batik lovers or users often do not understand about the information contained from the batik itself [7].Nowadays, people tend to prefer modern batik because their motives are more expressive, more cheerful, and not rigid so they can be combined with anything to suit their tastes [7].Lack of interest and knowledge about classical batik become one of the challenges in this modern era, so it takes a media that is able to pack the knowledge to become a fun thing. One medium that can be quite effective to collaborate is the game [8].The selection of game as one of the solutions reinforced by the statement that Indonesia is the second place as a gaming market in Southeast Asia with an investment of $47 \%$ or equivalent to US \$ 321 million. However, only $10 \%$ of local gaming industry players take the opportunity, while for local developers only contribute only 1.2\% [9].

Therefore, the creation of educational games for the community packaged in mobile devices is a practical step that can be selected as an interactive learning media and easy to carry anywhere.

\section{LITERATURE REVIEW}

\section{Batik and Classical Batik}

Batik is an image or painting made on top of calico using a tool called canting. Batik is a development (a way of creating) art in Central Java [10].

Based on the pattern or motive, batik is divided into two types, classical batik and modern batik or coastal batik [3]. Classic batik is ancient batik that is still rich with tradition and contains various elements and custom philosophy in it [3].

Classical batik can be grouped based on the ornaments in it. Here are some classic batik types that are grouped by the ornaments in it [7]:
A. Motif Parang
- Motive Parang Barong

Parang Barong is a machete motif commonly used by kings or as an official dress in public places [7].

- Parang Curiga means Keris, so the shape of this motif is the curves of the Keris repeated [7].

- This motif describes the shape of a machete-shaped curved or a form of fishing rod to be called a Parang Pancing [7].

B. Geometry Motif

Geometric motifs have been found in objects that existed during antiquity, classified in geometric motifs as composed of geometric ornaments [7].

1. Kawung Group

- Kawung Beton, this motif is called beton because its shape is like beton (Javanese language) which means jackfruit seed [7].

- Kawung Picis, this motif belongs to the small kawung type. Picis is so called because its shape resembles the smallest penny currency [7].

2. Nitik Group

Nitik motif is composed of dots and broken lines that if at first glance similar to woven fabric or woven motif. For Solo and Yogya area, this motif has black base color, while for Pekalongan area has green or blue base color [11]. One example of nitik is Nitik Rengganis. Nitik Rengganis is adapted from the country of South India, and is often depicted in the fairy tale as Dewi Rengganis [7].

3. Banji Group

Banji motif is a motif from China. This motif is derived from two words of "ban" which means ten and "dzi" which means many happiness or fortune, so that can be interpreted as happiness or fortune that abound. These motifs are usually interconnected with lines [7].

- Banji, a banji motif that has not experienced much variation is an early ancient motif [7]. 
- Banji Guling, this rectangularshaped motif that has ornaments in its [7].

\section{Non-Geometry Motif}

Non-geometric motives are grouped into 4, water plants, creeping plants, flowers, and animals in nature [7]. Motifs composed of plant ornaments are widely developed in the northern coastal areas of Java, Madura and Bali [11].

1. Water Plants motif, for example is Ganggong Lerep, term lerep means resting or sleeping [7].

2. Creeping Plants Motif, for example is Kirno Monda, kirno in this motif means the number 1.000 .000 whereas monda means more than others [7].

3. Flowers Motif, for example is Truntum derived from the word collect (treasure). This motif is composed of flower ornaments of the headland and combines with other motives that are spread evenly. This motif is usually worn by the bride's parents at the wedding ceremony [7].

4. Animal Motif, for example is Kupang Gandrung. Gandrung means to be in love or in love, so this motif describes a butterfly in love [7].

\section{Educational Game}

The educational game according to Bahri in Nugroho (2011) is any form of game that can create an atmosphere that is educational for the benefit of every learner [12].

\section{Android}

Android is a combination of software on mobile devices that include operating systems, middleware, and major applications [13].

\section{Unity}

Unity is a game engine used to develop games in various platforms. Unity can be used to unify art, sound, animation, objects, and functions in creating a product. The programming language used in this engine mostly uses C\#, besides Unity can also handle and support the creation of assets from the file with Blender, Maya, Adobe Photoshop, and Adobe Illustrator [14].

\section{Mindset Based On Gender}

Fredman and Schustack (2008: 79) say that usually men have more accentuate spatial ability, while women have more emphasis on the verbal ability [15]. Linn and Petersen: 1985 (in Kosa, Q: 2008) state that spatial ability is a mental process for prescribing something, remembering, creating, transforming, storing, and analyzing wake-ups [16]. L.L Thurstone, who classifies the intelligence into 7 primary abilities, argues that the ability of verbal (language) is the ability to capture ideas derived from language and language skills, verbal factors, and has the symbol "V" [12].

\section{Classical Conditioning}

Classical conditioning is the process by which a non-response stimulus is associated with a second stimulus, consequently the first stimulus will generate a response [17].

\section{Cognitive By Age}

Papalia, Old, and Feldman in his Human Development (2009) about the stages of cognitive development from a holistic point of view, say that at the age of 12-15 people have widespread memories, are able to use reasoning, and reach the stage of formal operations. And when humans turn 16 or 20 years old or into adulthood Knowledge continues to grow and can use reasoning to solve problems [18].

\section{RESEARCH METHODOLOGY}

\section{Method of collecting data}

Data collection methods used are as follows:

1. Questionnaire

The questionnaire was conducted by questioning 50 respondents in Central Java and outside Central Java, related to the existing research. Questions were disseminated before and after research conducted online (Google Forms).

2. Literature Review 
Literature review was done by collecting data through books, journals, papers, or other media that had to do with this research.

3. Observation

Observation was done by searching online and offline information from games that ever existed and tried out some games about batik in the Play Store.

\section{Game Development Method}

In designing the game on this classic Batik, we need a plan so that the application will run a structure. The game will be made as follows:

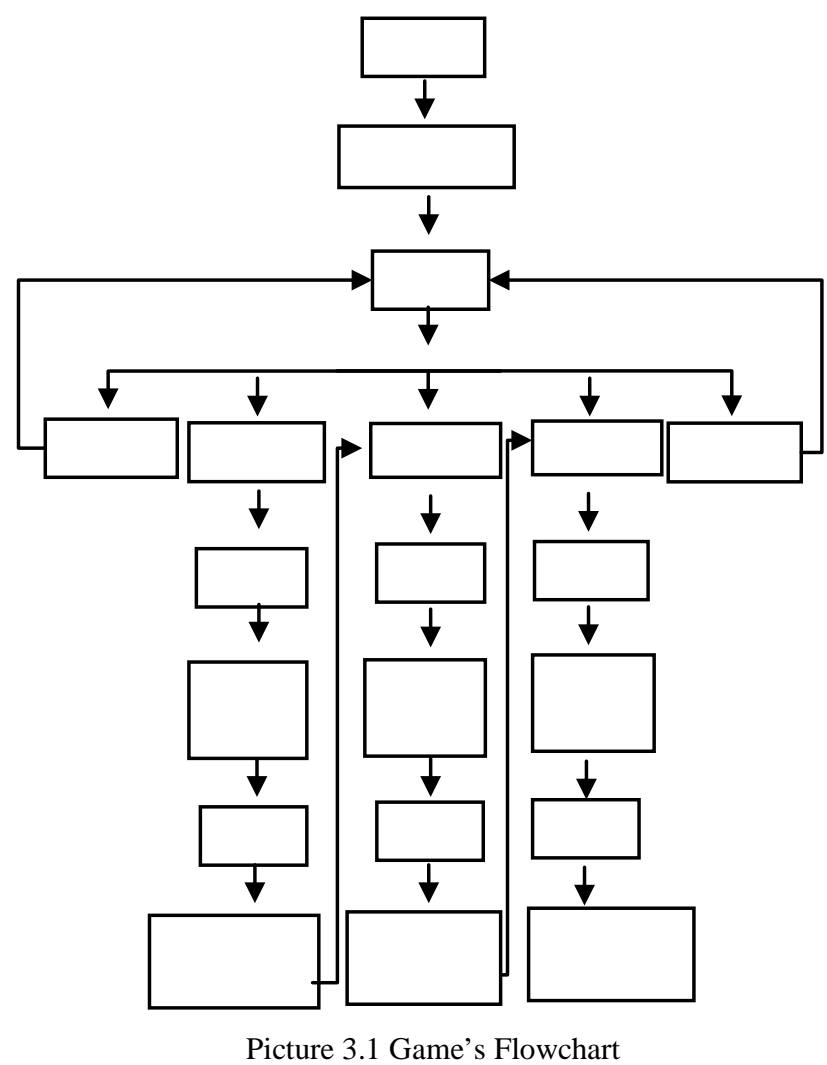

Game about the classic batik with the name Finding Batik will be packed in android platform by displaying classic batik information in the form of pop ups and menu information that can be read repeatedly. In addition, this game is also made in the genre of slide scrolling game and real-time strategy.

\section{RESULTS AND DISCUSSION}

After conducting a study with 50 respondents from Central Java and outside Central Java, where respondents were asked to fill out the pretest and post-test questionnaires, the following results were obtained:

\begin{tabular}{|c|c|c|c|}
\hline Origin & Yes & No & Total \\
\hline Know about Batik & & & \\
\hline Central Java & 36 & 0 & 36 \\
\hline Outside Central Java & 14 & 0 & 14 \\
\hline Total & 50 & 0 & 50 \\
\hline
\end{tabular}

The result was 36 respondents said "Yes" because they knew batik and hadworn batik, so as 14 respondents from outside Central Java.

\begin{tabular}{|c|c|c|c|}
\hline \multicolumn{1}{|c|}{ Know about } & Yes & No & Total \\
Classic Batik & & & \\
\hline Central Java & 11 & 25 & 36 \\
\hline Outside Central Java & 3 & 11 & 14 \\
\hline Total & 14 & 36 & 50 \\
\hline
\end{tabular}

But from 50 respondents only 11 respondents from Central Java and 3 people from outside Central Java who knew the classic batik so that they answered "Yes", while the rests were not.

\begin{tabular}{|c|c|c|c|c|}
\hline \multicolumn{1}{|c|}{$\begin{array}{c}\text { Total } \\
\text { Classic Batik }\end{array}$} & $\begin{array}{c}\text { Don't } \\
\text { Know } \\
\text { Batik }\end{array}$ & $\begin{array}{c}1-3 \\
\text { batik }\end{array}$ & batik & Total \\
\hline Central Java & 20 & 13 & 3 & 36 \\
\hline Outside Central Java & 9 & 5 & 0 & 14 \\
\hline Total & 29 & 18 & 3 & 50 \\
\hline
\end{tabular}

Before the respondents were asked to play educational games Finding Batik only 18 respondents who could mention 1-3 classic batik names, while who did not know at all there were 29 respondents and who were able to mention more than 3 classic batik there were only 3 respondents. 


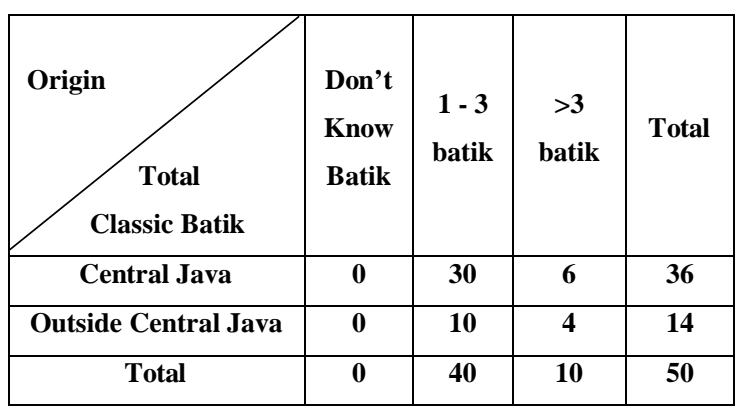

After the respondents played the game Finding Batik, the knowledge of the respondents increased. From the total of 30 respondents from Central Java and 10 respondents from outside Central Java couldname 1-3 batik motifs, while those whocould mention more than 3 classic batik were only 6 respondents from Central Java and 4 respondents from outside Central Java.

\begin{tabular}{|c|c|c|c|}
\hline Origin & Yeaning \& \\
Yos & & No & Total \\
\hline Philosophy Batik & & & \\
\hline Central Java & 4 & 32 & 36 \\
\hline Outside Central Java & 0 & 14 & 14 \\
\hline Total & 4 & 46 & 50 \\
\hline
\end{tabular}

Before the respondents played the game, only 4 respondents from Central Java answered "Yes" to state that they knew about the meaning and philosophy of classical batik.

As many as 32 respondents from Central Java and 14 respondents from outside Central Java answered "No" because they did not

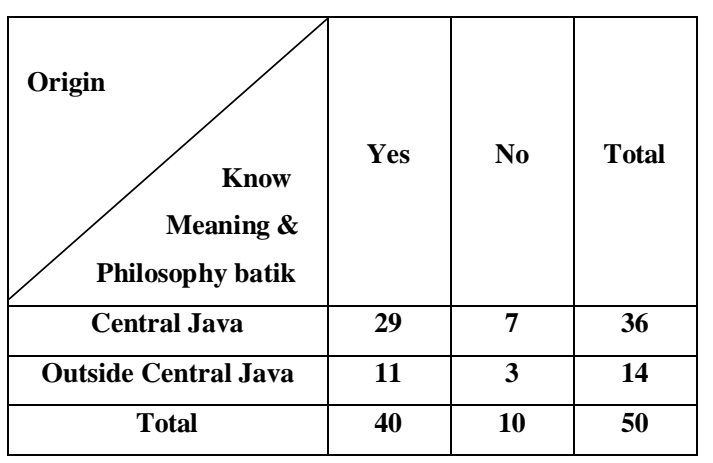
kno $\mathrm{w}$ at all. after the ondents played the game, the respondents' knowledge increased. Respondents, who answered "Yes" as a statement that they knew and could name the classical batik,were 29 from Central Java and 11 from outside Central Java, while who said "No" only 10 respondents as a whole.
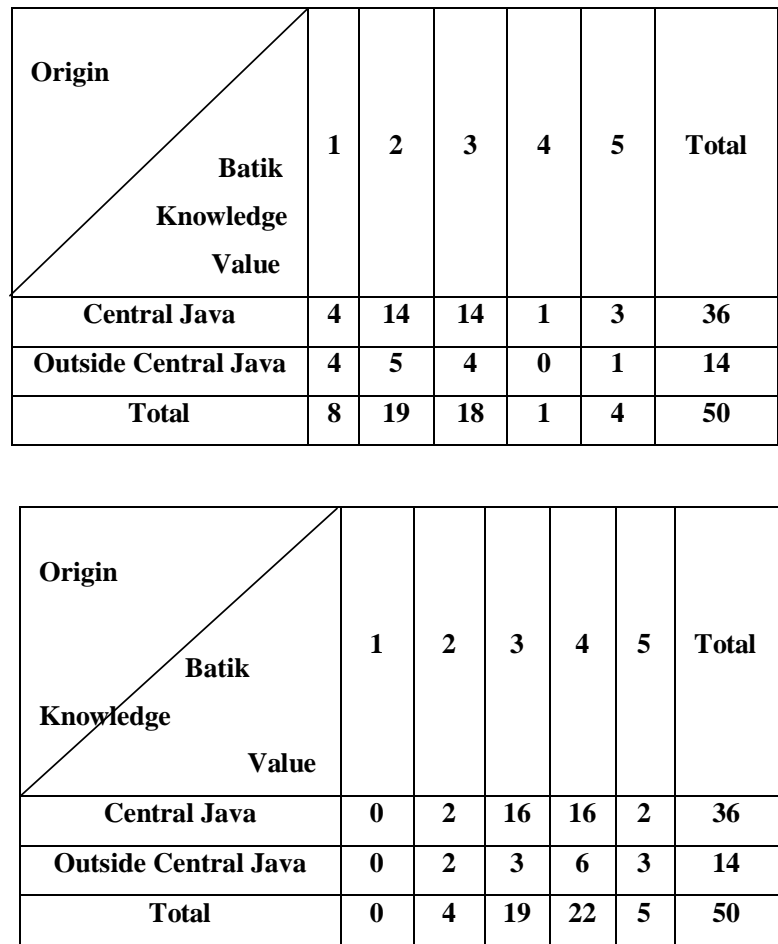

For the value of respondents on their knowledge about batik, the first beginning in number 2 and 3 as many as 19 and 18respondents increased so that knowledge of respondents at most were in number 3 and 4 with the number of respondents:19 and 22 respondents.

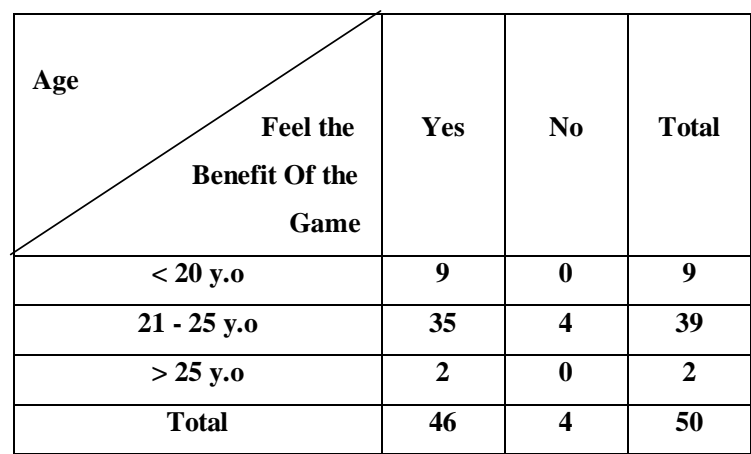

Apparently, respondents felt the benefits of the game, as many as 9 people of the $<20$ years age group, 35 people from the age of 21 - 25 years, and 2 people from age $>25$ years stated "Yes" because they felt the benefits. 
While those who did not feel and answer "No" only 4 people aged 21-25 years.

\section{CONCLUSIONS}

1. Game Finding Batik can provide knowledge about the introduction of the meaning and philosophy of classical batik to people both coming from Central Java and outside Central Java.

2. The appearance of repetitive information can make a person more remember the information presented, especially with the evaluation such as trivia quiz in the game, as Ivan P. Pavlov puts forward in the theory of classical conditioning.

3. The results of the reviews of respondents indicated an increase in knowledge, it could be seen from the individual assessment of each respondents about the quality of knowledge gained before playing the game and after playing the game, where the origin of respondents who did not know about classical batik amounted to 29 people, then 40 respondents were able to mention at least 1 to 3 kinds of classic batik name.

4. In the making of this game, it still had shortcomings, including only available on android platform only, the type of batik that was displayed did not cover all types of classic batik, and loading games was sometimes still long.

\section{ACKNOWLEDGMENT}

The authors gratefully acknowledge to Excellence Scholarship support from Bureau of Planning and International Cooperation, Ministry of Education and Culture of Indonesia.

\section{REFERENCES}

[1] M. H. Kasiyan, "Batik Riwayatmu Kini : Beberapa Catatan tegangan Kontestasi," Pros. Semin. Nas., pp. 121, 2010.

[2] S. dan S. Budi and R. Endah, "Reinterpretasi Enam Motif Batik
Klasik Surakarta sebagai Sumber Ide Penciptaan Desain Batik Motif Baru dalam mendukung Pengembangan Industri Kreatif,” 2014.

[3] Batik Nusantara, "Jenis Batik," indonesia.gunadarma.ac.id, 2016. [Online]. Available: http://indonesia.gunadarma.ac.id/batik/i ndex.php?option=com_content\&view= article\&id=206\&Itemid=29. [Accessed: 22-Aug-2016].

[4] C. Tresnadi and S. Agus, "Identification of Values of Ornaments in Indonesian Batik in Visual Content of Nitiki Game,” J. Arts Humanit., vol. 04, no. 08, pp. 25-39, 2015.

[5] K. Sindo, "Dunia Semakin Mencintai Batik,” Kementrian Perindustrian Republik Indonesia, 2016. [Online]. Available:

http://www.kemenperin.go.id/artikel/68 27 /Dunia-Makin-Mencintai-Batik. [Accessed: 18-Aug-2016].

[6] B. Anas, "Batik Dalam Tantangan Modernitas,” Pararupa, no. 02, pp. 20 27, 2008.

[7] A. Kusrianto, Batik: Filosofi, Motif, dan Kegunaan, 1st ed. Yogyakarta: Andi, 2013.

[8] C. Supriadi, "Industri Game , Pasar Lama Peluang Baru," http://www.marketing.co.id/, Jakarta, pp. 1-2, Feb-2016.

[9] F. Riana, "Berpotensi Besar, Industri Game Lokal Akan Dikembangkan Pemerintah,” 2016. [Online]. Available:

https://m.tempo.co/read/news/2016/01/ 24/090738831/berpotensi-besar-

industri-game-lokal-akan-

dikembangkan-pemerintah. [Accessed: 25-Aug-2016].

[10] D. Hamzuri, Batik Klasik, 4th ed. Djambatan, 1981.

[11] G. Yosef, "Filsafat Sebagai Dasar Kajian Dalam Penerapan Motif Seni Batik Klasik," J. Ilm. PRABANGKARA, vol. 14, no. 1412-0380, pp. 73-81, 2011.

[12] F. Y. Al Irsyadi and Y. S. Nugroho, 
“Game Edukasi Pengenalan Anggota Tubuh Dan Pengenalan Angka Untuk Anak Berkebutuhan Khusus (ABK) Tunagrahita Berbasis Kinect," Pros. SNATIF, vol. 2, pp. 1-8, 2015.

[13] A. K. Saha, What Is Android, no. January. http://developer. android. com/guide/basics/what-is-android. html, 2011.

[14] S. Dhuri, P. Zha, P. Nehete, S. Khot, and P. M. Devmane, "Game Development for Android Device using Unity 3D,” vol. 4, no. 5, pp. 3-6, 2015.

[15] E. Fuadi, "Perbedaan Gender Dalam Mengambil Keputusan Menjadi Wirausaha Pada Usaha Kecil Menengah (UKM) Di Kota Pekanbaru,” Universitas Islam Negeri Sultan Syarif Kasim Riau, 2014.
[16] M. P. Toto Subroto, S.Si, "Kemampuan Spasial (Spatial Ability),” Pros. Semin. Nas. Pendidik. Mat., no. April, 2012.

[17] R. A. Powell and P. L. Honey, Introduction to Learning and Behavior, 3rd ed. Michele Sord.

[18] S. Rahmatillah, P. Meilinda, S. Saukiyah, V. Okta, Anggun, and C. Dwi, "Perkembangan Kognitif Anak Sejak Lahir Hingga Dewasa,” Jember, 2014. 